\title{
Lektura ma głos ${ }^{1}$
}

Krystyna Koziołek

TEKSTY DRUGIE 2021, NR 1, S. 205-214

DOI: 10.18318/td.2021.1.13 | ORCID: 0000-0002-0727-1781

K ażda książka ma swoją historię - genezę, tajniki aktu twórczego, okoliczności i miejsce wydania, historie kolejnych edycji, ingerencje wydawców, projekty okładek, liczbę sprzedanych egzemplarzy, chłostę lub lukier recenzji. Każda książka ma też mikrohistorię, historię intymną, historię swojej lektury. Aby mieć do niej dostęp, książki winny być zaopatrzone w aneksy, które stworzyłyby ogromny, nieskończony cykl, na przykład pod tytułem „Komedia czytania”.Jego kompozycją rządziłby osobliwy splot łączący książkę i sytuacje jej lektury. Na razie jednak ktoś, biorąc do ręki mój egzemplarz Buszującego w zbożu, nie usłyszy fragmentu L.A. Woman, a czytając mojego Stachurę, nie będzie nucił melodii Nobody Home grupy Pink Floyd. A do tego smaki jedzenia i napojów, których ślady tkwią pewnie gdzieś między kartkami, wreszcie epopeja ciała wędrującego z fotela na sofę, z sofy na podłogę

1 Recenzja książki: R. Chartier Czy książki wywołują rewolucje? Szkice z historii ksiq̨żki, lektury i kultury piśmiennej, red. i posłowie P. Rodak, Wydawnictwa UW, Warszawa 2019.
Krystyna Koziołek doktor habilitowana, profesor Uniwersytetu Śląskiego, literaturoznawczyni. Jej zainteresowania badawcze koncentrują się na teorii i praktyce lektury, dydaktyce, komparatystyce, związkach nauk humanistycznych i medycznych. Wchodzi w skład Rady Naukowej serii wydawniczych ars medica ac humanitas i Nowa Edukacja. Jest autorką monografii poświęconych czytaniu: Czas lektury (2017) oraz Czytanie z innym: etyka, lektura, dydaktyka (2006). 
w poszukiwaniu optymalnej pozycji. Ralph Waldo Emerson wyznał podobno, że Platon zawsze mu się kojarzył z zapachem wełny, czytał go bowiem w zimnym pokoju, przykryty kocami aż po brodę2. Jerzy Pilch w Spisie cudzołożnic kreślił obraz matki, która w stroju kąpielowym porządkuje księgozbiór, a jej „rozgrzane nieoczekiwaną gimnastyką ciało pachnie olejkami do opalania i zapach ten na zawsze łączy się z zapachem protestanckich broszur"3. A przecież dźwięki, smaki i zapachy wplecione w historię lektur to dopiero początek, rama sytuacyjna, koloryt indywidualnej lektury. A co z wielkimi zdarzeniami czytania, które naznaczają je wyrwą; olśnieniem, którego doświadczam, kiedy okazuje się, że „złamałam szyfr” i odkryłam, iż autor jest prorokiem, a ja bohaterem przepowiedni, którą właśnie czytam... To jedna z tajnych, nigdy niespisanych historii świata, których mizernym śladem są podkreślenia i uwagi na marginesach. To nie żywoty książek, ale historie czytania domagają się głosu. Właśnie, głosu lub pisma, które wymagają porzucenia intymności dla jawności, wypowiedzenia tego, co wydaje się wyłącznie pomieszaniem zmysłów i wyobraźni, które naznaczyły ciało czytelnika i papier książki. Ale „doświadczanie owej przyjemności - pisze Anna Burzyńska - jest przecież doznaniem głęboko intymnym, osobistym, tajemniczym, niewyrażalnym i nieprzekazywalnym" ", chcąc więc historię tych doświadczeń opowiedzieć, trzeba porzucić fantazje o czystej lekturze i zgodzić się, że czytamy głównie po to, aby mówić lub pisać. Dlatego badacze skupieni wokół tej problematyki utrzymują, że najłatwiej dotrzeć do czytelnika, który czyta na głos, a brak wiedzy o indywidualnym akcie lektury można próbować przełamać badaniem wszelkich zapisków, wspomnień, pamiętników lekturowych, marginaliów, słowem: świadectw lektury. Swoisty manifest historii czytania (nie mylić z historią czytelnictwa czy historią książki) ogłosił w 1986 roku Robert Darnton, publikując tekst „Pierwsze kroki w stronę historii czytania”' Darnton, poszukując metody badań nad czytaniem, mówi o tzw. zewnętrznej i wewnętrznej historii czytania. Zewnętrzna historia koncentruje się na szukaniu odpowiedzi na pytania: kto czyta? (rasa, klasa, płeć...), co czyta?, gdzie (w jakim miejscu, w jakiej pozycji) i kiedy? Wewnętrzna historia czytania

2 A. Manguel Moja historia czytania, przeł. H. Jankowska, Muza, Warszawa 2003, s. 86.

3 J. Pilch Spis cudzołożnic. Proza podróżna, Wydawnictwo Literackie, Kraków 2002, s. 68.

4 A. Burzyńska Teoria i lektura: niebezpieczne zwiq̨zki. „Pamiętnik Literacki” 2003 Z. 1, s. 104.

5 R. Darnton First steps toward a history of reading, "Australian Journal of French Studies" 1986 vol. 23. Omawiam na podstawie edycji w zbiorze The history of reading. A reader, ed. by Sh. Towheed, R. Crone, K. Halsey, London-New York 2011. 
ma za cel badanie indywidualnego aktu lektury, jest zatem poszukiwaniem odpowiedzi na pytania, dlaczego i jak czytamy. Kilka lat po książce Darntona ukazała się „Historia czytania na Zachodzie” pod redakcją Guglielma Cavalla i Rogera Chartiera ${ }^{6}$. Jak pisze Anna Zdanowicz:

Za szczególnie istotne wydawcy uznali odtworzenie zapomnianych dziś zwyczajów czytelniczych (na przykład głośnej lektury) oraz ciągłe przypominanie o tym, że czytelnicy nigdy nie obcowali z abstrakcyjnymi tekstami, lecz z dziełami w konkretnej materialnej formie, a ich zachowania zmieniały się w zależności od czasu, miejsca i środowiska.?

W konsekwencji badacze historii czytania zaproponowali dwa konwencjonalne i moim zdaniem rozsądne podejścia do problemu. Mianowicie ujęcie makro- i mikroanalityczne. Pierwsze zbiera wszelkie dowody praktyk czytania: nakłady, katalogi wypożyczeń w bibliotekach, wyniki sprzedaży, sieci dystrybucji książek, reklamy ${ }^{8}$. Drugie, mikroanalityczne podejście ma za zadanie zbadać, jak konkretny czytelnik czyta $\mathrm{i}$ jak na lekturę reaguje. W czasie ostatnich trzech dekad ukazało się wiele książek i artykułów, w których czytanie i czytelnik mają głos. Także poza murami uniwersytetów. Za sprawą interdyscyplinarności studiów nad lekturą akt czytania, jego przypadki i historie zaczęły budzić coraz większe zainteresowanie. Czułość dla odnalezionych śladów lektury i talent do opowieści Alberta Manguela sprawiły, że książka Moja historia czytania stała się bestselerem również w Polsce i wzorcem dla tzw. książek o książkach. Dzięki internetowi możliwość zapisu własnych doświadczeń lekturowych i dzielenia się nimi stała się udziałem także czytelników „nieprofesjonalnych”. Tylko w polskich zasobach znajdziemy blisko sto blogów o czytaniu, których bohaterami są nie tylko autor bloga i opisywana przezeń książka, ale też komentujący wpisy goście. Podobne zapisy znajdziemy na stronach wydawnictw i księgarń internetowych. Trend ten stał się ogólnoświatowy i ponaddyscyplinarny. Anonimowi dotąd czytelnicy wyszli

6 A history of reading in the West, ed. by G. Cavallo, R. Chartier, transl. by L. Cochrane, University of Massachusetts Press, Amherst, MA 1995.

7 A. Zdanowicz Odtwarzanie historii czytania: syntezy, monografie i nowe propozycje badawcze. Przegląd anglojęzycznych prac z historii czytelnictwa, wydanych w latach 1992-2011, „Roczniki Biblioteczne" 2012 nr 56, s. 193.

8 Przykładem takiej pracy jest np. W.St. Clair The Reading Nation in the Romantic Period, Cambridge University Press, Cambridge 2004. 
na powierzchnię ukrytej, niedostępnej dotąd historii. To nie badacze dotarli do nich, lecz przemiany technologii i demokratyzacja mediów pozwoliły im się ujawnić i wypowiedzieć lub choćby zaznaczyć swoje doświadczenia czytelnicze. Świadectwa pojedynczych doświadczeń lektury budzą często lekceważenie badaczy. Opowieści o prywatnych historiach czytania są interesujące, ale zwykle uważane za dyletanckie i nieprofesjonalne, przepełnione nostalgią za utraconą niewinnością lektury9 . Ja także, w poczuciu pewnego zawstydzenia swoimi lekturowymi poruszeniami, uwiedziona książką Manguela, fotografiami Kertesza i Hammonda z ich albumów On reading, zaczęłam poszukiwać naukowego opracowania fenomenu czytania w jego uwikłaniach historycznych i społecznych. W mojej bibliotece pojawiły się m.in. książki z serii „Communicare”, a jedną z nich były rozmowy Pawła Rodaka z Le Goffem, Chartierem, Hébrardem i Lejeunem, zebrane pod tytułem Pismo, książka, lektura. Z książki tej pamiętam zwłaszcza odkrycie swoistej misji historii czytania, którą jest - zdaniem Hébrarda - dowartościowanie czytelnika i pokazanie jego kluczowej roli w poznawaniu historii kultury. Tak pojęta historia czytania nie jest jedynie historią przeczytanych książek - jest historią społecznych relacji do wiedzy, do autorytetów, ewolucji modeli wychowywania i systemu edukacji. Kilka lat później w tej samej serii Wydawnictw Uniwersytetu Warszawskiego ukazały się Narodziny książki Luciena Fabvre'a i Henri-Jeana Martina, z posłowiem Pawła Rodaka. Zamysł autorów zmierzał do ukazania historii książki jako narzędzia myślenia. Książka jest nie tylko przedmiotem, towarem podlegającym prawom rynku, lecz przede wszystkim nośnikiem idei. Historycy książki mają więc niezmierzone pole badań, natomiast badacze doświadczenia lektury uświadamiają sobie jeszcze wyraźniej, że historia czytania nie może być zaledwie częścią historii książki, ponieważ liczba i rodzaj przeczytanych książek nie mówi nam wiele o praktyce czytania. Jak pisze Gabriel Zaid: „nie chodzi o to, ile książek przeczytaliśmy, ale w jakim stanie nas zostawiły”"10.

Z końcem 2019 roku w serii „Communicare” ukazała się monografia Rogera Chartiera Czy książki wywołują rewolucje? Szkice z historii książi, lektury i kultury piśmiennej. Profesor Roger Chartier jest francuskim historykiem z kręgu "Annales”, specjalizującym się w dziejach książek. Do 2016 roku wykładał w Collège de France oraz na uczelniach amerykańskich, głównie w Filadelfii.

9 Piszę o tym szerzej w swojej książce Czas lektury, Wydawnictwo UŚ, Katowice 2017.

10 G. Zaid So many books: reading and publishing in an age of abundance, transl. by N. Wimmer, Paul Dry Books, London 2003, s. 24. 
Do dziś prowadzi gościnne wykłady i seminaria poświęcone historii książki i historii lektury. Jest autorem ponad trzydziestu książek. Artykuły Chartiera przełożyły dla polskiego czytelnika Olga Dawidowicz-Chymkowska, Anna Leyk, Magda Rodak i Joanna Stryjczyk. O wyborze dziewięciu tekstów zdecydował Paweł Rodak. Zamieszczone w jednym tomie, układają się w prywatną historię czytania (Chartiera i Rodaka). Dla Chartiera, jak czytamy w Przedmowie autora, jest to okazja, „by prześledzić drogę prowadzącą od historii książki do historii lektury"11. Badacz przyznaje, że wybrane przez Rodaka teksty stworzyły fundament dla jego późniejszych poszukiwań. Na brak bardziej aktualnych wątków z refleksji Chartiera nie pora narzekać, gdyż sam autor już we wstępie zapowiada możliwość opublikowania po polsku drugiego tomu swoich artykułów. Poczekajmy.

Publikację otwiera tekst z 1974 roku: Książka: zmiana perspektywy, który Roger Chartier opublikował wraz Danielem Roche. Ten współautorski rozdział jest zapowiedzią problemów, które francuski badacz będzie rozwijał w licznych późniejszych pracach. Rozdział jest interesujący dla historyka, literaturoznawcy, socjologa, antropologa... słowem dla każdego, kogo interesują studia nad słowami i znakami. Autorzy podkreślają, że „historia książki nie obawia się zapuszczać na teren innych dyscyplin" (s. 37). Jest to więc, po pierwsze, spojrzenie na książkę jako towar. Sporo tu liczb, uczeni prezentują bowiem dane, pochodzące głównie z badań ilościowych. W rozdziale przeczytamy także o produkcji książek w XVII- i XVIII-wiecznej Francji. Produkcji legalnej (monopol Paryża) i nielegalnej (prowincja), o handlu brukowcami i literaturą popularną. Zapowiadana w tytule rozdziału „zmiana perspektywy” pozwala szybko porzucić statystykę, by zwrócić naszą uwagę na materialną formę książki: ilustracje, typografię, okładkę. Artykuł ma także swoich bohaterów - zróżnicowanych klasowo i majątkowo czytelników. Zawartość następnych studiów Chartiera można rozpiąć na planie trójkąta, którego wierzchołki wyznaczają książka, tekst i lektura. Fakt, że lektura jest pojedynczym wydarzeniem rozgrywającym się w umyśle i ciele czytelnika, sprawia, że jej historia, teoria i systematyka są szczególnie trudne do skonstruowania ze względu na przygodność, indywidualizm oraz intymność aktu czytania. Lektura jako synonim czytania łączy jego antagonistyczne warianty: instytucję i doświadczenie, przymus i przyjemność. Polszczyzna w nieprzeliczonych frazeologizmach przechowuje to opozycyjne rozumienie lektury: bierna,

11 R. Chartier Czy książki wywołują rewolucje?, s. 7. Kolejne cytaty z omawianej książki zaznaczam w tekście numerem strony w nawiasie. 
twórcza, krytyczna, relaksująca, powtórna, obowiązkowa, zakazana, zajmująca, nudna, pochłaniająca, urwana... Od kiedy bezgłośne czytanie oczami stało się normą, czytelnik mógł posiąść tekst na wyłączność, bez konieczności udzielania go innym. Dokonało się tym sposobem nagłe zniknięcie pewnego obszaru ludzkiej aktywności, która co prawda nie zanikła, ale przemieściła się poza scenę publiczną. Uwewnętrzniona, stała się domeną umysłu, wyobraźni, intelektu, ale nie głośnej mowy. Odtąd zaś tropiący lekturę może już tylko badać ślady lektury pozostawione w książkach lub podpatrywać czytające ciała, upozowane na obrazach. W rozdziale Odksiążi do czytania z 1993 roku Chartier przywołuje kilkadziesiąt obrazów (głównie z XVIII wieku). Są one źródłem poszukiwania odpowiedzi na pytania: kto i jak czytał, w jakim otoczeniu czytano, w jakiej pozycji, stroju i nastroju? Z minianaliz portretów „namalowanych" czytelników Chartier tworzy obrazy czytających kobiet i mężczyzn w XVIII wieku. Wobec ciągłego niedosytu wiedzy o lekturze rozdział kończy nostalgiczna puenta: „Najczęściej sama książka pozostaje jedynym źródłem informacji o sposobie jej czytania. Stąd biorą się bolesne ograniczenia całej historii lektury, a jednocześnie jej nieodparty urok" (s. 76).

Kolejny rozdział (Wspólnoty lekturowe) to tekst z 1996 roku, dedykowany pamięci Michela de Certeau. Dziś pewnie tytuł doprowadziłby nas przede wszystkim do tzw. social reading, czyli wspólnego czytania w sieci' ${ }^{12}$. Dla Chartiera jednak kategoria wspólnoty lekturowej jest tym, czym dla Stanleya Fisha „wspólnota interpretacyjna”, która określa kulturowe możliwości lektury i obiektywizuje wykładnię znaczenia tekstu. Zdaniem Fisha/Chartiera nikt nie czyta tak, jak chce. Bo choć lektura jest swobodną praktyką, jest zarazem zdeterminowana przez wiele czynników kulturowych, takich jak płeć, przynależność religijna, solidarność związana z byciem częścią danej wspólnoty, tradycje edukacyjne (s. 83). Autor postuluje takie badania historyczne, które brałyby również pod uwagę, jak te same teksty były przyswajane (uchem czy okiem) i w jakiej formie wydawniczej (wykwintnej, pełnej szacunku dla tekstu czy niestarannej, pełnej skrótów i uproszczeń). Rozdział następny (Lektury "popularne), z 1996 roku, stanowi przekonujący głos w sprawie koniecznej ostrożności w definiowaniu pojęć. Podobnie jak kultura „popularna”, lektury „popularne” domagają się, zdaniem autora, wymiennego przyjmowania dwóch perspektyw badawczych: uznania autonomiczności, tego, co

12 Zob. W. Kotras Czytanie społecznościowe: platformy, aplikacje, chmury i tagi-przeglad problematyki, https://repozytorium.umk.pl/bitstream/handle/item/5690/TSB.2018.007\%2CKortas. pdf? sequence $=1$ (27.02.2020). 
„popularne”, oraz podporządkowania temu, co dominujące. Praktyki lekturowe obejmują nie tylko literaturę, lecz całe uniwersum symboliczne. Kłopot w tym, że oczywistość i powszechność pojedynczego aktu lektury daje się zapisać, ale próby stworzenia modelu lektury rażą obcością i nieadekwatnością w odniesieniu do jednostkowego doświadczenia czytania, które bywa pasywne, podporządkowane bądź odkrywcze, niepowtarzalne. Rozdział ten jest etyczną lekcją dla każdego badacza kultury popularnej, by nie ulegać pokusom generalizacji i protekcjonalności.

Rozdział tytułowy powstał w roku 2000. Czy książi wywołują rewolucje? Tak, ponieważ książki „zawierały treści abstrakcyjne, odległe od praktyki spraw codziennych oraz podważały autorytety krytykując tradycję" (s. 127). Nie, bo to nie książki, ale ich lektura ma moc zmieniania czytelników. W swoich analizach Chartier zabiera nas znów do wieku XVI, XVII i XVIII. Wybór ten jest znaczony dwiema rewolucjami - rewolucją Gutenberga i Wielką Rewolucją Francuską. W jakimś sensie można powiedzieć, że jedna przygotowała drugą. Rosnąca wraz z upowszechnieniem druku liczba czytelników zwiększyła popyt na książki. Nie tylko ilościowy, lecz także zapotrzebowanie na nowe lektury. Świat czytelników domagał się propozycji wykraczających poza ramy książek religijnych. Rynek wydawniczy coraz śmielej, dzięki pozwoleniom oficjalnym i milczącym przyzwoleniom, zaczął wytwarzać szerszy repertuar tytułów. Ci, którzy nie mogli pozwolić sobie na kupno książki, mieli możliwość za niewielką opłatą skorzystać z tzw. gabinetów lektury. Skandalizujący posmak tej nazwy nie jest wielkim nadużyciem, zważywszy na to, że czytano tam głównie pamflety, satyry, kroniki skandali i literaturę pornograficzną. Sławę "złych książek" zyskały też książki filozoficzne. Przykład Voltaire’a dowodzi, że „dzieła filozofów dzielą ten sam los, co książki gorszące”(s. 143). Chartier każe nam pamiętać, że nie możemy zakładać takiego samego odbioru przez wszystkich czytelników ani jednego prostego przesłania ideologicznego (s. 155). Głos wywrotowy, rewolucyjny ma lektura, z całą jej wewnętrzną dynamiką i zróżnicowaniem.

"Jak umiejscowić w długiej historii książki, lektury i ich związków z pismem tę rewolucję - zapowiadaną, a faktycznie już rozpoczętą - która oznacza przejście od książki takiej, jaką znamy, z jej składami, arkuszami, stronami, do tekstu elektronicznego i lektury z ekranu?" (s. 174) To jedno z pytań postawionych przez Chartiera w rozdziale Reprezentacje pisma z 1996 roku. Zmiana zachodząca na naszych oczach jest zasadnicza, ponieważ zmienia się budowa i struktura nośnika tekstu. Znika rozróżnienie pisania i czytania, autora i czytelnika, znika materialność książki. Głos Chartiera w tej kwestii nie 
jest wyłącznie nostalgiczny. Badacz z fascynacją obserwuje, jak „możliwość przekazywania tekstów na odległość i zlikwidowanie nieprzekraczalnego do tej pory dystansu między tekstem a czytelnikiem sprawia, że spełnienie tego dawnego marzenia staje się wyobrażalne, znajduje się na wyciągnięcie ręki" (s. 187). W erze tych przemian, zdaniem uczonego, zobowiązanie gromadzenia i inwentaryzowania wytworów kultury kodeksu jest warunkiem ocalenia piśmiennictwa przeszłości.

„Kim jest autor?” - to kolejny problem, z jakim mierzy się Chartier (rozdział z 1996 roku Postacie autora). Badacz skromnie zastrzega, że „nie pretenduje do odpowiedzi na to pytanie” (s. 230). Przywołuje jednak pewien niemożliwy do zaakceptowania paradoks dotychczasowych dociekań naukowych, iż „historia książki jest historią bez czytelników i bez autorów” (s. 194). Tradycyjnie pojmowana historia książki koncentrowała się bowiem na jej formie materialnej, na historii edycji, rynku księgarskim oraz samym tekście.

O związkach pisania i czytania dowiemy się z rozdziału Kultura piśmienna i literatura w czasach nowożytnych z 2001 roku. Chartier postuluje, by nie oddzielać historii pisma od historii książki, jak czyniono w tradycji tych dyscyplin. W artykule znajdziemy sporo informacji na temat czytających kobiet i emancypacyjnym potencjale sztuki pisania. Czytelnikiem można być, słuchając lektora, ale dopiero opanowanie umiejętności pisania prowadzi nas do zyskania podmiotowości. I chodzi tu zarówno o sygnaturę, podpis, jak i wszelką twórczość. Chartier sięga do przykładów tzw. zapisków powszednich i listów. Zwraca także uwagę na funkcję "pisarza”, sporządzającego tekst w imieniu osoby niepiśmiennej, który podobnie jak lektor umożliwia dostęp do kultury graficznej, kultury pisma.„Uczenie się pisania - podsumowuje Chartier - jest trudne, a praktykowanie go jeszcze trudniejsze, ale opanowanie tej sztuki otwiera nowe możliwości, oferując temu, kto je posiadł, większą kontrolę nad swoim życiem" (s. 245).

Najnowszy tekst w tomie, Od historii książki do historii kultury piśmiennej, powstał w 2014 roku i jest swoistym podsumowaniem ostatnich 50 lat badań nad książką. Z kwestii nieporuszanych w poprzednich rozdziałach warto zwrócić uwagę na wyjście z cienia pomijanych bohaterów historii czytania - tzw. pierwszych czytelników, czyli cenzorów; kopistów, korektorów, tłumaczy. Rozdział ten jest też manifestem otwarcia się historii książki na nowe wyzwania, wynikające z rewolucji cyfrowej, do której badacz odnosi się z entuzjazmem i ostrożnością, z pokorą przyznając, że jako historyk jest tylko „biednym prorokiem przyszłości” (s. 281). 
Odbiór tekstu literackiego, co w omówionych już tekstach wielokrotnie podkreślał Roger Chartier, jest warunkowany historycznie zmiennymi kodami lektury, realizowanymi przez czytelnika w procesie czytania. Proces ten odbywa się pod wpływem podwójnej determinacji: zewnętrznego wobec czytelnika środowiska lektury, tj. „wspólnoty czytających” (Kant), „pola literackiego” (Bourdieu), „przestrzeni czytania” (de Certeau) oraz konkretnych praktyk rozumienia, interpretowania i wartościowania tekstu, które stanowią realizację społecznych kodów lektury. Dlatego dobrze się stało, że Paweł Rodak zamieścił w książce zapis debaty między Rogerem Chartierem i Pierre'em Bourdieu. To niezwykle pożyteczny rozdział, który jest wielokrotną odpowiedzią na pytanie: „co właściwie robimy, kiedy czytamy?” (s. 295). Tu zamiast omówienia wybrałam dwa cytaty. Tym razem z wypowiedzi Pierre'a Bourdieu:

Wierzę, że lektura i czytanie są bardzo ważne, a ten, kto nie czyta, jest czegoś pozbawiony. Żyję w imię takiego przekonania. (s. 292)

W książce czytelnik znajduje to, co sam do niej wnosi, czego bez niej nie umiałby wypowiedzieć. (s. 299)

Dzięki świetnemu posłowiu Pawła Rodaka, Historia książki i historia lektury według Rogera Chartiera, możemy prześledzić pokrótce biografię naukową Chartiera oraz być bliżej rozumienia i próby scalenia jego naukowych dokonań. Swoim studentom zawdzięczam uwagę, że umieszczenie posłowia w miejscu wstępu dobrze zrobiłoby lekturze całości.

Czy książki wywołują rewolucje? Chcę wierzyć, że w pewnym sensie tak, skoro naturalną skłonnością czytelnika jest poszukiwanie w książkach wiedzy, porady, kształcącego przykładu, modelu życia. Dzięki książkom mamy szansę uprawiania ćwiczeń z wyobraźni nie tylko jako gimnastyki umysłu czy pobudzania kreatywnego myślenia. Możemy kształtować zdolność tworzenia alternatywnych wizji społecznych, ekonomicznych i politycznych. W jaki sposób wykorzystamy ten potencjał, jakim echem odbiją się głosy naszych lektur, ocenią kiedyś historycy czytania, późni uczniowie Rogera Chartiera. 


\section{Abstract}

\section{Krystyna Koziołek}

UNIVERSITY OF SILESIA (KATOWICE)

Reading Has a Voice

Review: Roger Chartier, Czy książki wywołują rewolucje? Szkice z historii książki, lektury $i$ kultury piśmiennej [Do Books Cause Revolutions? On the History of the Book, Reading and Print Culture], University of Warsaw, Warsaw 2019

\section{Keywords}

Roger Chartier, Paweł Rodak, reading, history of reading, history 